

\section{Financing Projects That Use Clean-Energy Technologies: An Overview of Barriers and Opportunities}

D.P. Goldman

New Energy Capital, LLC

J.J. McKenna

Hamilton Clark \& Co.

L.M. Murphy

National Renewable Energy Laboratory

Prepared under Task No. 7200.2010 


\section{NOTICE}

This report was prepared as an account of work sponsored by an agency of the United States government. Neither the United States government nor any agency thereof, nor any of their employees, makes any warranty, express or implied, or assumes any legal liability or responsibility for the accuracy, completeness, or usefulness of any information, apparatus, product, or process disclosed, or represents that its use would not infringe privately owned rights. Reference herein to any specific commercial product, process, or service by trade name, trademark, manufacturer, or otherwise does not necessarily constitute or imply its endorsement, recommendation, or favoring by the United States government or any agency thereof. The views and opinions of authors expressed herein do not necessarily state or reflect those of the United States government or any agency thereof.

Available electronically at http://www.osti.gov/bridge

Available for a processing fee to U.S. Department of Energy and its contractors, in paper, from:

U.S. Department of Energy

Office of Scientific and Technical Information

P.O. Box 62

Oak Ridge, TN 37831-0062

phone: 865.576 .8401

fax: 865.576 .5728

email: mailto:reports@adonis.osti.gov

Available for sale to the public, in paper, from:

U.S. Department of Commerce

National Technical Information Service

5285 Port Royal Road

Springfield, VA 22161

phone: 800.553 .6847

fax: 703.605.6900

email: orders@ntis.fedworld.gov

online ordering: http://www.ntis.gov/ordering.htm 


\title{
Financing Projects That Use Clean-Energy Technologies: An Overview of Barriers and Opportunities
}

\author{
Daniel P. Goldman - Managing Director - New Energy Capital, LLC \\ John J. McKenna - Managing Director - Hamilton Clark \& Co. \\ Lawrence M. Murphy - Manager, Enterprise Development Program, National Renewable \\ Energy Laboratory
}

\section{Defining Project Financing}

Project finance is asset-based financing, meaning that the project lenders have recourse only to the underlying assets of a project. It involves both debt and equity, where the debt-to-equity ratio is typically large (e.g., 70\% debt to 30\% equity). Debt is used when available and when it is the least expensive form of financing (Figure 1), with equity still needed for credit worthiness. Most important, revenue from the project must be able to generate a return to the equity investors, and pay for interest and principal on the debt, transaction costs associated with developing and structuring the project, and operations and maintenance costs.

Successful project financing must provide a structure to manage and share risks in an optimal way that benefits all participants, allocating risks to those entities that are able to mitigate each specific risk, and to share information about putting risk management in the proper hands at the proper stage of project development.

Contractual agreements are, thus, important in risk mitigation. Today's project financing typically involves the creation of a stand-alone project company (Figure 2) that is the legal owner of the project assets, and that has contractual agreements with other parties, such as purchasers of the products, suppliers, lenders, investors, sponsors, operators, insurers; and firms that engineer, procure, and construct the project. Traditionally, project financing has focused on large-scale projects - typically greater than $\$ 500$ million. In contrast, clean-energy projects are typically much smaller, whose size does not allow them to easily absorb high administrative and

\begin{tabular}{|c|c|c|}
\hline Project Cost, \$K & & 10,000 \\
\hline Ánual Net Revenue, $\$ \mathrm{~K}$ & & 1468 \\
\hline Debt Interest Rate, \% & & \\
\hline Term, Yrs & & 12 \\
\hline Simple example with no tax or & All & Debt \& \\
\hline salvage effects considered & Equity & Equity \\
\hline Debt / Equity & 0/100 & 70/30 \\
\hline Debt, $\$ \mathrm{~K}$ & 0 & 7000 \\
\hline Equity, $\$ \mathrm{~K}$ & 10000 & 3000 \\
\hline Debt Payment to Lender, $\$ \mathrm{~K}$ & 0 & 835 \\
\hline Cash Flow to Equity Holder, $\$ K$ & 1468 & 633 \\
\hline IIRR from Cash Flow, \% & 10 & 18 \\
\hline
\end{tabular}

In this example, the cash flow gives a 10\% IRR for the all equity investment, and $18 \%$ IRR for the $30 \%$ equity and 70\% debt (@ a 6\% loan interest) investment. Note that the sum of payments to debt and equity investors equals project revenues.

Figure 1. A Highly Simplified Example Showing Leverage when Debt Interest is Lower than the Return on an All-Equity Investment transaction costs.

Examples of clean-energy projects include: an ethanol plant using new biomass conversion technology, a manufacturing facility for photovoltaics, an apartment building that is installing water-metering equipment, a large landfill that wants to deploy Stirling engines to generate electricity from methane, or a fleet manager who wants to convert delivery trucks to hybrid-drive systems. 


\section{The Importance of Project Financing for Clean-Energy Technology Deployment}

Typically, neither the manufacturer nor the purchaser can self-finance, nor are they able to secure financing using their non-project assets. So, project financing is often the only way energytechnology companies can move their products from early adopter customers to mainstream customers. Project financing is, thus, a crucial enabler on the critical path to large-scale deployment of these technologies. Consequently, the ability to attract an affordable combination of debt, equity, and other sources of funding for the project is key to commercial success.

Other financial players also have a stake in the ultimate availability of project financing. For instance, the public sector has invested a lot of money in R\&D for these

Figure 2. Example Project Structure Showing Numerous Contractual Relationships

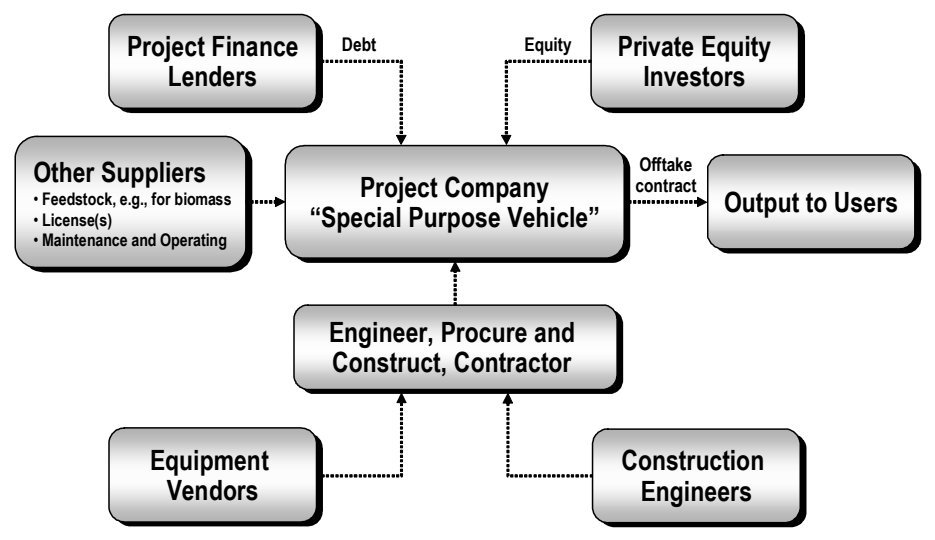
technologies, and its goals depend on their eventual commercialization. Further, while there clearly is a gap between venture capital and project financing, venture capitalists want to see a clear path to commercialization even in their early venture investments. Project financing availability also enables follow-on venture investment to occur at less expensive pricing.

The way risk sharing is allocated today, and the role that contractual agreements play in risk mitigation, this also suggests that there is a need to develop a shared mindset on technology (and other) risks by all the involved participants. For financing to occur, the divergent views of different investors must be reconciled.

\section{Key Challenges Involved in Financing Clean-Energy Technology Projects}

Clean-energy projects present risks in terms of technology, credit worthiness, revenue security and market competition risk, each of which is discussed below. In addition, other issues within the larger context of today's project financing industry adds to these challenges. For example, in the utility arena, even where projects use proven conventional technologies, the recent over-supply of electric capacity from merchant power plants have made project financing in the deregulated electric market difficult to obtain-especially the debt portion. Also, restructuring in the utility industry has resulted in other difficulties; e.g., the credit worthiness of utilities that agree to purchase the power from projects cannot always be assumed to be good a-priori; and, in cases where transmission and generation resources have been de-bundled, access to the transmission cannot always be assured.

\footnotetext{
${ }^{1}$ Venture capitalists don't normally directly invest in projects. The time frames are typically too long, and the exit strategy, as well as the returns are often not adequate for $\mathrm{VC}$ needs.
} 
Further, it should be noted that each clean-energy technology will have a different risk profile. For example, wind projects using well-established wind turbines may have virtually no perceived technical risk (though they have a resource-availability risk). But a pioneering biomass-to-ethanol plant may have significant perceived technical risk (though little or no resource-availability risk).

Key specific risks are addressed next, each followed by suggested ways to address them.

\section{Technology Risk}

Project investors worry foremost about technology risk. This worry must be effectively addressed as a prerequisite to any dialogue with lenders and equity investors, or they won't provide financing. Project-financing lenders will not accept the risk that the technology will be unable to perform consistently in a commercial setting to commercial standards over the life of the project. Nor will they accept the risk that a technology will become prematurely obsolete - a concern that arises when a project involves a state-of-the-art technology in an industry whose technology is rapidly evolving.

One key challenge with many clean-energy technologies is that there is often no information on which to make comparisons, or no experience base or track record in the marketplace, which is needed for due diligence and risk assessment by the project financiers. Hence, technology risk is a particularly thorny issue with the plants employing new technology (e.g., some wind farms using newer turbine designs) that is manufactured by an early-stage company, and that carry high costs because of their innovative and less-mature nature.

It also should be recognized that different investors along the technology-maturation spectrum often interpret technology risk differently; and/or have different tolerances for that risk. For example, a public-sector sponsor of high-risk R\&D tends to see less risk than a venture capitalist, who, in turn, tends to see less risk than a project financier, who wants to accept no technical risk and to see welldocumented technical verification and acceptance in the marketplace. Often the most optimistic view is held by the entrepreneur, who has progressed through a working bench model, an alpha test, and a pilot-scale site that seems to be working - and who thinks commercialization is close at hand.

Recommended first steps: This suggests the need for a financing bridge between beta and commercial products, a form of high-yield project financing for early-stage commercial products. In addition, it is important for financiers to know the hurdles that energy technology entrepreneurs are dealing with in the market. They also need to stay current on the state of the technology, to know what customers and consultants are actually saying about markets, and to think creatively about how to accept later-stage technology risks.

\section{Credit Worthiness Risk}

The amount of debt a project can raise is a function of the project's expected capacity to service debt from project cash flow-or, more simply, its credit strength. Typically, a project has no operating history at the time of its initial debt financing. In general, a project's credit strength derives from (1) the inherent value of the assets included in the project; (2) the expected profitability of the project; (3) the amount of equity that project sponsors have at risk (after debt financing is completed); and, indirectly, (4) the pledges of credit-worthy third parties or sponsors involved in the project.

With many projects based on clean-energy technology, especially with relatively new technology, credit worthiness is a concern to lenders. Often the relatively new clean-energy technology not only 
lacks sufficient testing and verification, it also lacks sufficient acceptance in the marketplace. Plus, the technology is frequently manufactured by an early-stage company that may have a weak balance sheet and no credit track record. This credit issue is compounded when the start-up company manufactures the technology and acts as the project owner (in such cases the project is de facto the company, whose viability depends on project success).

Recommended first steps: Credit worthiness for clean-energy projects can be enhanced by integrating and monetizing all appropriate tax benefits and incentives in the project-financing plans, in a way that credit risk is minimized-also consider the use of insurance from nontraditional sources, subordinated debt, and loan guarantees from third parties (and maybe even from venture capital investors). Again, appropriate project structuring is key.

\section{Revenue Security Risk}

According to the Massachusetts Renewable Energy Trust, another formidable risk is the need for revenue security over the time required to pay back the capital investment. To address this issue, the Trust has implemented "put" and "put back" options for clean-energy projects. Also, because renewables tend to be so capital intensive, most of the costs must be amortized over a long period of time if debt is to become available. Fifteen years, for example, is a common requirement in New England.

Recommended first steps: Revenue security is, of course, greatly enhanced where power purchase, or other off-take agreements (e.g. from the Connecticut Clean Fund for certain projects) are available. Also, in addition to the "put" option approaches mentioned above, recent innovations in finance, including currency futures, other options, interest-rate swaps and caps, and currency swaps, have provided project sponsors with new vehicles for managing certain types of project-related risks more cost-effectively while securing revenue.

\section{Market Competition Risk}

For instance, clean- and renewable-energy technology projects often have higher capital costs than projects utilizing traditional power-generation technologies. Further, if the renewable resource is limited (e.g., for a solar plant that can only operate when the sun shines), then cash flows and margins will be lower when compared to fossil plants and, thus, put further pressure on overhead and maintenance costs. This can make them more difficult to finance, to the extent that their revenues are limited by the price of electricity (which is based on the cost of producing it using the cheaper traditional technologies-unless government intervenes through such mechanisms as renewable portfolio standards).

Funding sources sometimes see this as indicating that the technology will become outdated, thus posing a risk that the project in question will have difficulty performing and generating sufficient revenues for the term of the financing. On the other hand, especially if the technology does not utilize a feedstock that must be purchased, the full life-cycle costs of the project may be competitive or superior to a traditional alternative whose revenues are sensitive to feedstock costs.

Recommended first steps: Over time, the capital costs of these projects will become more competitive as manufacturing costs drop due to increased production or decrease in per-unit cost, and as the cost of project development drops through learning and standardization. Be willing to accept loan guarantees from third parties (and maybe even from venture capital investors) that fall away when the project meets the test of technology commercialization or when the market risk has been mitigated by a minimum throughput or minimum sales level. 


\section{Scale and Related Cost Issues}

Size matters. Distributed generation ("DG") projects using renewable energy are typically smaller than large infrastructure projects that tend to dominate the project-financing industry today. This should be evident since DG is meant to be smaller, located nearer to the customer and therefore not requiring costly transmission and distribution ("T\&D") infrastructure. Large projects have a competitive advantage because they can absorb large due-diligence and transaction costs. With the small size of many renewable-energy projects, due-diligence and transaction costs can make the cost of project financing prohibitive.

Recommended first steps: For scale issues, one answer is to develop "cookie cutter" project financing documentation that might have a high initial transaction cost for the first project but would have lower costs for subsequent projects because lenders are willing to accept uniform documentation. Due-diligence costs will naturally reduce over time as lenders become more familiar with renewable-energy projects. In addition, it may be possible in some cases to bundle multiple projects, having dissimilar risk characteristics, together into a portfolio of projects that has lower risk characteristics than any single project.

\section{Some Final Thoughts for Enhancing Project Financing Availability}

Entrepreneurs must understand the most strenuous tests that investors will put them through before writing checks. They won't get money from any investor — whether public or private-if they don't meet the investor's needs. Hence, understanding the needs of financiers is a required first step in developing a more effective working relationship among entrepreneurs, lenders, and investorsespecially with respect to risks such as those related to technology and markets.

Financiers can also benefit, and thereby help increase the yield on their investments and loan portfolios, if they develop a better understanding of early-stage energy technologies and their inherent risk profiles - and if they integrate this understanding into their project lending and investment criteria early on. This can be accomplished by (1) involving themselves in the planning stage of energy-technology projects prior to the time that the company is seeking financing; (2) seek to better understand the underlying technology risk and the specific issues for a given project, instead of assuming that all new-technology projects are inherently risky; (3) organize a briefing for their credit committees and commitment committees, which would cover issues specific to advanced and renewable-energy projects; and (4) actively participate in energy technology venues such as the NREL Industry Growth Forums.

Finally, based on the discussion above, we emphasize the need to develop a place in the company's capital structure between venture capital financing and (traditional) project financing.

This, again, clearly points to the need for a financing bridge between working models of the technology and commercial products and the associated project financing.

\section{For more information}

Esty, Benjamin C. (2004). Modern Project Finance. New York: John Wiley and Sons.

Finnerty, John D. (1996). Project Financing: Asset-Based Financial Engineering. New York: John Wiley and Sons. 


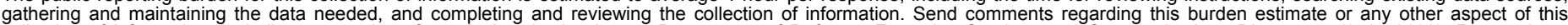

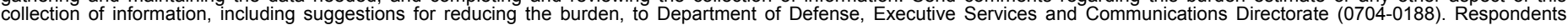

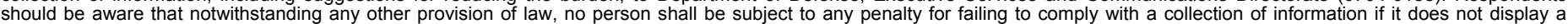
currently valid OMB control number.

PLEASE DO NOT RETURN YOUR FORM TO THE ABOVE ORGANIZATION.

\begin{tabular}{l|l|l|l} 
1. REPORT DATE $(D D-M M-Y Y Y Y)$ & 2. REPORT TYPE & 3. DATES COVERED (FrOm - TO)
\end{tabular} October 2005

Technical Report

4. TITLE AND SUBTITLE

Financing Projects That Use Clean-Energy Technologies: An

Overview of Barriers and Opportunities

D.P. Goldman, J.J. McKenna, and L.M. Murphy 5a. CONTRACT NUMBER

DE-AC36-99-GO10337

5b. GRANT NUMBER

5c. PROGRAM ELEMENT NUMBER

5d. PROJECT NUMBER

NREL/TP-600-38723

5e. TASK NUMBER

7200.2010

5f. WORK UNIT NUMBER

7. PERFORMING ORGANIZATION NAME(S) AND ADDRESS(ES)

National Renewable Energy Laboratory

1617 Cole Blvd.

Golden, CO 80401-3393

9. SPONSORING/MONITORING AGENCY NAME(S) AND ADDRESS(ES)
8. PERFORMING ORGANIZATION REPORT NUMBER

NREL/TP-600-38723

10. SPONSOR/MONITOR'S ACRONYM(S) NREL

11. SPONSORING/MONITORING AGENCY REPORT NUMBER

12. DISTRIBUTION AVAILABILITY STATEMENT

National Technical Information Service

U.S. Department of Commerce

5285 Port Royal Road

Springfield, VA 22161

13. SUPPLEMENTARY NOTES

14. ABSTRACT (Maximum 200 Words)

Project finance is asset-based financing, meaning that the project lenders have recourse only to the underlying assets of a project. It involves both debt and equity, where the debt-to-equity ratio is typically large (e.g., $70 \%$ debt to $30 \%$ equity). Debt is used when available and when it is the least expensive form of financing, with equity still needed for credit worthiness. Most important, revenue from the project must be able to generate a return to the equity investors, and pay for interest and principal on the debt, transaction costs associated with developing and structuring the project, and operations and maintenance costs. Successful project financing must provide a structure to manage and share risks in an optimal way that benefits all participants, allocating risks to those entities that are able to mitigate each specific risk, and to share information about putting risk management in the proper hands at the proper stage of project development. Contractual agreements are, thus, important in risk mitigation. Today's project financing typically involves the creation of a stand-alone project company that is the legal owner of the project assets, and that has contractual agreements with other parties.

\section{SUBJECT TERMS}

Project financing; clean-energy technologies; asset-based financing; debt-to-equity ratio; risk sharing; venture capital; private sector; deployment; credit worthiness; market competition; distributed generation; Daniel P. Goldman; John J. McKenna; Lawrence M. Murphy

\begin{tabular}{|l|l|l|l|l|}
\hline \multicolumn{3}{|l|}{ 16. SECURITY CLASSIFICATION OF: } & $\begin{array}{c}\text { 17. LIMITATION } \\
\text { OF ABSTRACT }\end{array}$ & $\begin{array}{c}\text { 18. NUMBER } \\
\text { OF PAGES }\end{array}$ \\
\hline $\begin{array}{l}\text { a. REPORT } \\
\text { Unclassified }\end{array}$ & $\begin{array}{c}\text { b. ABSTRACT } \\
\text { Unclassified }\end{array}$ & $\begin{array}{c}\text { c. THIS PAGE } \\
\text { Unclassified }\end{array}$ & $\begin{array}{c}\text { UL } \\
\end{array}$ &
\end{tabular}

19a. NAME OF RESPONSIBLE PERSON
19b. TELEPHONE NUMBER (Include area code)

